\title{
IDENTIFIKASI KANDUNGAN METABOLIT SEKUNDER DAN UJI AKTIVITAS ANTIOKSIDAN EKSTRAK n-HEKSANA KULIT JERUK BALI (Citrus maxima Merr.).
}

\section{Identification of Secondary Metabolite Content and Antioxidant Activity Tests N- Hexan Extract Of Grapefruit Peel (Citrus maxima Merr.).}

\section{Elisabeth Oriana Jawa La I*}

\section{Repining Tiyas Sawiji ${ }^{2}$}

Ni Made Rai Yuliani ${ }^{3}$

*'Sekolah Tinggi Farmasi

Mahaganesha, Denpasar,Bali, Indonesia

2Sekolah Tinggi Farmasi

Mahaganesha, Denpasar,Bali, Indonesia

3Sekolah Tinggi Farmasi Mahaganesha, Denpasar,Bali, Indonesia

*email: echaoriana07@gmail.com

\begin{abstract}
Abstrak
Latar belakang: Penyakit degeneratif disebabkan karena antioksidan yang ada didalam tubuh tidak mampu menetralisir peningkatan konsentrasi radikal bebas, sehingga perlu adanya antioksidan dari luar untuk menghancurkan radikal bebas yang dapat menyebabkan kerusakan sel. Kulit buah jeruk bali (Citrus Maxima Merr.) merupakan salah satu tanaman yang diketahui memiliki kandungan metabolit sekunder namun pemanfaatan kulit jeruk bali belum sepenuhnya dimaksimalkan.

Tujuan: Menganalisis kandungan senyawa kimia dan efek antioksidan ekstrak nheksana kulit buah jeruk bali (Citrus maxima Merr.).

Metode : Identifikasi kandungan senyawa kimia dilakukan dengan skrining fitokimia dan dipertegas dengan analisis profil kromatografi lapis tipis ekstrak, sedangkan uji aktivitas antioksidan dilakukan menggunakan metode penangkapan radikal 2,2-difenilI-pikrilhidrazil (DPPH) dengan trolox sebagai pembanding.

Hasil : Hasil identifikasi ekstrak kulit buah jeruk bali (Citrus maxima Merr.) mengandung metabolit sekunder berupa flavanoid, alkaloid, triterpenoid/steroid, dan tanin. Hasil uji aktivitas antioksidan ekstrak kulit buah jeruk bali (Citrus maxima Merr.) dan trolox masing-masing menunjukkan nilai IC ${ }_{50}$ I I I,69 ppm dan 17,04 ppm. Dari hasil pengujian ini ekstrak kulit buah jeruk bali (Citrus maxima Merr.) memiliki aktivitas antioksidan yang sedang jika dibandingkan trolox.
\end{abstract}

Kata Kunci:

Aktivitas antioksidan

DPPH

$I C_{50}$

Kulit Jeruk Bali

Skrining Fitokimia

\begin{abstract}
Background :Degenerative diseases triggered by antioxidants in the body are unable to neutralize the increased concentration of free radicals that can cause cell damage, so to destroy free radicals it is necessary to have antioxidants from outside the body. Grapefruit peel (Citrus Maxima Merr) is one plant that is known to have a lot of secondary metabolite content however it is not fully utilized.

Objective: To analyze the content of chemical compounds and the antioxidant effect of n-hexane extract of Grapefruit peel (Citrus maxima Merr.)

Method: Identification of chemical compounds was carried out by phytochemical screening and confirmed by the analysis of the extract thin layer chromatography profile, whereas the antioxidant activity test was carried out using the radical capture method of 2,2-diphenyl-I-picrylhydrazyl (DPPH) with Trolox as a comparison.

Results: The results of the identification of Grapefruit peel (Citrus maxima Merr) extracts is containing secondary metabolites in the form of flavonoids, alkaloids, triterpenoids/steroids, and tannins. The results of antioxidant activity test extracts of grapefruit peel (Citrus maxima Merr) and Trolox each showed values that: I $C_{50}$ I I I.69 ppm and 17,04 ppm. From the results of this test, the extract of grapefruit peel (Citrus

maxima Merr) has moderate antioxidant activity when compared to Trolox.
\end{abstract}

Keywords:

Antioxidant activity

DPPH

Grapefruit peel,

phytochemical screening

\section{PENDAHULUAN}

Perubahan gaya dan pola hidup di masyarakat saat ini sebagai salah satu dampak perubahan pola konsumsi menyebabkan terjadinya peningkatan berbagai penyakit degeneratif (Andriani, 2007). Radikal bebas terlibat dalam penyakit degeneratif seperti diabetes, kerusakan hati, inflamasi, kanker, gangguan jantung, gangguan syaraf dan proses penuaan (Onkar et al., 20/2) 
Radikal bebas merupakan atom atau gugus atom apa saja yang memiliki satu atau lebih elektron tidak berpasangan sehingga bersifat sangat reaktif dimana akan secara terus menerus terbentuk didalam tubuh dan jika jumlah dalam tubuh semakin banyak dapat berpotensi menonaktifkan berbagai enzim pengoksidasi lemak dan mengganggu DNA tubuh sehingga terjadi mutasi sel yang merupakan awal timbulnya kanker (Kuntorini \& Asuti, 20l0).

Radikal bebas terbentuk ketika molekul terpecah menjadi elektron tidak berpasangan atau dikenal dengan reaksi oksidatif. Antioksidan merupakan senyawa yang dapat menghambat reaksi oksidasi, dengan cara mengikat radikal bebas dan molekul yang sangat reaktif. Salah satu bentuk senyawa oksigen reaktif adalah radikal bebas, senyawa ini terbentuk di dalam tubuh dan dipicu berbagai faktor (Winarsi, 2007). Ketersediaan antioksidan pada tubuh haruslah memenuhi jumlah yang memadai, sebab dalam kondisi tertentu seperti pada keadaan patogenik akibat terbentuknya jumlah radikal bebas yang berlebih dapat memicu penurunan fungsi kerja dari enzim-enzim yang memiliki peranan sebagai antioksidan endogen (Astuti, 2012).

Menurut sumbernya antioksidan dapat dikelompokkan menjadi 2 yaitu antioksidan alami dimana senyawa antioksidan ini secara alami terdapat dalam tubuh sebagai mekanisme pertahanan tubuh normal maupun berasal dari asupan luar tubuh dan antioksidan sintesis yang merupakan hasil sintesis secara kimia (Tristantini et al., 20/6). Antioksidan mampu mencegah reaksi berantai radikal bebas dengan mekanisme menyumbangkan elektron sehingga dapat menghindari kerusakan oksidatif pada molekul target, seperti protein, lipida dan DNA (Halliwell, 1994)

Tumbuhan memiliki kandungan metabolit primer dan metabolit sekunder. Tumbuhan dapat menghasilkan produk organik sekunder (metabolit sekunder) yang merupakan hasil akhir dari suatu proses metabolisme (Ergina et al., 20/4). Metabolit sekunder berperan dalam mempertahankan diri dilingkungan tempatnya tumbuh dan merupakan biomolekul yang digunakan sebagai lead coumpound dalam penemuan dan perkembangan obat baru (Atun, 2005). Antioksidan yang berasal dari sumber tanaman umumnya berupa metabolit sekunder salah satunya adalah senyawa fenolik yang dapat berupa golongan flavonoid. Flavonoid memiliki kemampuan untuk meredam atau mereduksi radikal bebas dan juga sebagai anti radikal bebas (Zuhra et al., 2008).

Saat ini limbah kulit jeruk bali belum sepenuhnya termanfaat dengan baik dimana jumlah produksi jeruk bali di Indonesia mencapai $5 \mathrm{Il}$ kg/ton pertahunnya dengan limbah kulit jeruk bali sebesar 208 kg/ton (Rafsanjani \& Putri, 2014). Jeruk bali mengandung banyak komponen nutrisi dimana sebagian besar komponen tersebut terletak pada kulitnya antara lain terdapat kandungan senyawa alkaloid, flavonoid, likopen, vitamin $\mathrm{C}$, serta yang paling dominan adalah pektin dan tanin. Komponen fenolik yang terbanyak pada kulit buah jeruk bali ialah pektin dan tanin sebesar 23\%. Kulit buah jeruk bali (Citrus maxima Merr.) mengandung senyawa flavonoid yaitu naringin dan hesperidin (Choi et al., 2007). Hal ini dibuktikan berdasarkan penelitian yang dilakukan terhadap kandungan ekstrak etanol kulit jeruk bali dengan metode Kromatografi Lapis Tipis, terlihat bahwa kandungan senyawa flavonoid yang terkandung dalam ekstrak kulit jeruk bali (Citrus maxima Merr.) yaitu rutin, naringin, dan hesperidin (Dianingati et al., 20/3). Penelitian terkait kandungan senyawa aktif dalam kulit jeruk bali sudah banyak dilakukan, namun terdapat perbedaan tempat pengambilan sampel, jenis pelarut yang digunakan untuk ekstraksi juga ada perbedaan perlakuan dan pengujian sehingga perlu dikonfirmasi kembali melalui penelitian ini untuk menganalisis kandungan zat aktif dari ekstrak n-heksana kulit buah jeruk bali (Citrus maxima Merr.) dan aktivitas antioksidan $n$-hexan ekstrak kulit jeruk bali yang diperoleh dari daerah Klungkung, Bali. 


\section{METODOLOGI}

\section{Alat dan Bahan}

Alat yang digunakan dalam penelitan adalah blender serbuk, oven, tabung reaksi, kuvet, pipet tetes, batang pengaduk, corong kaca, beaker glass $100 \mathrm{ml}$ dan 250 $\mathrm{ml}$, cawan porselen, erlenmayer $250 \mathrm{ml}$, gelas ukur 10 $\mathrm{ml}, 50 \mathrm{ml}$ dan $100 \mathrm{ml}$, timbangan analitik, termometer, spatula logam, labu tentukur $10 \mathrm{ml}$ dan $100 \mathrm{ml}$, spektrofotometer UV-Vis, aluminium foil, Silica Gel 60 $F_{254}$, kertas saring, pipet ukur.

Bahan yang digunakan dalam penelitan adalah kulit buah jeruk bali, n-heksana, serbuk DPPH (2,2-difenil-Ipikrilhidrazil), aquadest, serbuk $\mathrm{Mg}, \mathrm{HCl}$ pekat, kloroform, larutan $\mathrm{NH}_{3}$, amil alkohol, eter, pereaksi Mayer, pereaksi Dragendroff, pereaksi Lieberman Burchard, larutan $\mathrm{FeCl}_{3} \mathrm{I} \%, \mathrm{H}_{2} \mathrm{SO}_{4}$, etil asetat, klorofom, methanol, butanol, asam asetat glasial, $\mathrm{H}_{2} \mathrm{SO}_{4} \mathrm{I} 0 \%$.

\section{Metode Penelitian dan Jalannya Penelitian}

Metode yang digunakan beserta alur kerja sebagai berikut:

\section{Determinasi Tanaman}

Determinasi tanaman dilakukan di Balai Konservasi Tumbuhan Kebun Raya “Eka Karya” Bali Lembaga Ilmu Penelitian Indonesia, Candikuning, Baturiti, Tabanan.

2. Pembuatan Simplisia

Buah Jeruk Bali dicuci di air mengalir, kemudian dikupas untuk dipisahkan dari kulitnya. Pada saat pengupasan untuk memisahkan kulitnya diusahakan pengirisan kulit tidak terlalu tebal sehingga didapat bagian kulit terluarnya. Kulit jeruk bali yang sudah dikupas dicuci diair mengalir dan ditiriskan kemudian ditimbang untuk mendapatkan berat basah dari simplisia. Tahap selanjutnya dilakukan perajangan untuk mempercepat proses pengeringan. Simplisia kemudian di oven dengan menggunakan suhu $50^{\circ} \mathrm{C}$ selama 3 hari hingga diperoleh simplisia kering. Simplisia kering kemudian ditimbang dan dihitung \% LOD. Simplisia kering dihaluskan dengan cara diblender dan diayak dengan ayakan mess 80 hingga diperoleh serbuk halus kemudian dihitung persentase kadar air dan dilanjutkan dengan pemeriksaan organoleptis yang meliputi bau, warna dan rasa.

\section{Ekstraksi}

Sebanyak 250 gram serbuk halus kulit jeruk bali (Citrus maxima Merr.) dimaserasi dengan pelarut $n$-heksana dengan perbandingan I : 8 dalam wadah kedap dan tertutup rapat. Proses maserasi berlangsung selama 5 hari dengan sesekali dilakukan penggojokan atau pengadukan untuk memaksimalkan proses penyarian. Maserasi dilakukan sebanyak 2 kali replikasi dengan perlakuan yang sama. Hasil maserasi kemudian disaring menggunakan kain flanel dan filtratnya dievaporasi dengan menggunakan rotary evaporator untuk mendapatkan ekstrak kental. Ekstrak kental kemudian ditimbang dan dihitung \% rendemen ekstrak.

\section{Skrining Fitokimia}

Pembuatan larutan uji untuk skrining fitokimia dengan melarutkan $500 \mathrm{mg}$ ekstrak dalam $50 \mathrm{ml}$ larutan yang sesuai, kemudian larutan sampel tersebut digunakan untuk pengujian selanjutnya.

\section{a. Alkaloid}

Sebanyak $2 \mathrm{ml}$ larutan uji diuapkan diatas penganas air, hingga diperoleh residu. Residu ditambahkan dengan 5 $\mathrm{ml} \mathrm{HCl} 2 \mathrm{~N}$. Setelah dingin, larutan disaring. Larutan dibagi ke dalam 3 tabung reaksi.

Tabung ke-I: Blanko

Tabung ke-2: ditambahkan 3 tetes pereaksi dragendroff Tabung ke-3: ditambahkan 3 tetes pereaksi mayer (melalui dinding tabung). Terbentuknya endapan jingga pada tabung kedua dan endapan kuning pada tabung ketiga menunjukan adanya alkaloid ( Farnsworth, 1966)

b. Flavonoid

Sebanyak I ml larutan uji dimasukan kedalam 3 tabung reaksi yaitu :

Tabung ke-I : Larutan blanko

Tabung ke-2 : Ditambahkan I ml larutan Pb Asetat $10 \%$ 
Tabung ke-3 : Penambahan beberapa tetes $\mathrm{NaOH}$ $20 \%$. Reaksi positif flavonoid jika terbentuk endapan berwarna kuning pada tabung 2. Pada tabung 3 positif flavonoid terbentuk larutan berwarna kuning (Ugochukwu et al., 20I3).

c. Saponin

Sebanyak $5 \mathrm{ml}$ larutan uji dimasukan kedalam tabung reaksi

Tabung ke-I : Blanko

Tabung ke 2 : Ditambahkan aquadest $5 \mathrm{ml}$ dikocok selama 30 detik. Reaksi positif yang terbentuk pada tabung 2 terbentuk busa selama 10 menit setinggi I-10 $\mathrm{cm}$ dan tidak hilang dengan penambahan I tetes larutan HCL 2N (Marliana et al., 2005).

\section{d. Triterpenoid/Steroid}

Sebanyak $2 \mathrm{~mL}$ zat ditambahkan $2 \mathrm{~mL}$ kloroform, kemudian ditambahkan $2 \mathrm{~mL}$ asam asetat anhidrat dan di tambahkan $2 \mathrm{~mL}$ asam sulfat pekat melalui dinding tabung. Terbentuk cincin berwarna hijau kebiruan menunjukkan adanya sterol, sedangkan jika terbentuk cincin kecoklatan atau violet pada perbatasan dua pelarut menunjukkan adanya triterpenoid (Jones dan Kinghom, 2006; Evans 2009)

e. Tanin

Sebanyak I ml larutan uji ditambahkan dengan larutan besi (III) klorida 10\% diaduk dan ditambahkan I ml asam sulfat pekat. Jika mengandung tanin maka akan terbentuk larutan berwarna hitam kehijauan atau hitam (Putri et al., 2013)

\section{Kromatografi Lapis Tipis}

Pada KLT ini meggunakan fase diam Silica $G_{60} F_{254}$. Plat KLT dibuat dengan Panjang $10 \mathrm{~cm}$ dan lebar $3 \mathrm{~cm}$.

a. Identifikasi Senyawa Flavonoid

KLT senyawa golongan flavonoid menggunakan fase gerak $n$-butanol : asam asetat : air dengan perbandingan (4:1:5) dan untuk penampakan noda menggunakan uap ammonia. Pengamatan akan di lakukan di UV $254 \mathrm{~nm}$ dan UV $365 \mathrm{~nm}$. Hasil menunjukkan positif flavonoid jika sebelum diuapkan dengan amnonia memberikan penampakah noda berwarna ungu gelap, fluoresensi biru muda, dan tidak tampak. Setelah diuapkan dengan ammonia akan memberikan penampakan noda berwarna kuning, hijau kuning atau coklat, biru muda, merah atau jingga, fluoresensi hijau kuning, atau hijau biru fluoresensi biru muda terang, fluoresensi biru muda terang hingga muda sesuai dengan jenis flavonoidnya (Hanani, 20I4)

b. Identifikasi senyawa Tanin

Fase gerak yang digunakan untuk mengidentifikasi senyawa tannin adalah methanol : air (6:4) dengan penampakan noda $\mathrm{FeCl}_{3} 5 \%$, dimana reaksi positif yang terbentuk adalah noda berwarna hitam (Banu \& Nagarajan, 2014)

c. Identifikasi Senyawa triterpenoid

Fase gerak yang digunakan untuk identifikasi senyawa triterpenoid adalah $n$-hexan : etil asetat dengan penampakan noda menggunakan pereaksi anisaldehid asam sulfat (Kristanti,2008)

d. Identifikasi Senyawa Saponin

Fase gerak yang digunakan untuk identifikasi saponin adalah kloroform ; methanol ; air dengan perbandingan $(6,2 ; 4,8 ; 0,97)$ dengan reaksi penyemprot untuk penampakan noda adalah anisaldehida asam sulfat.

6. Pengujian aktivitas antioksidan dengan DPPH (2,2-difenil- I-pikrihidraazil)

a. Pembuatan larutan induk ekstrak kulit buah jeruk bali konsentrasi 1000 ppm. Dibuat larutan induk ekstrak kulit buah jeruk bali konsentrasil 000 ppm dengan menimbang 0,050 gram ekstrak kental dimasukkan kedalam labu terukur kemudian ditambahkan dengan $\mathrm{n}$-heksan sampai $50 \mathrm{ml}$, lalu dikocok hingga homogen. Dari larutan induk 1000 Ppm dipipet $5 \mathrm{ml}$ dimasukkan dalam labu terukur $50 \mathrm{ml}$, kemudian tambahkan denga n-heksana sampai tanda batas sehingga diperoleh larutan baku 100 ppm.

b. Pembuatan larutan ekstrak $n$-hexan kulit jeruk bali dengan konsentrasi 5, I5, 30, 40,50 ppm 
c. Pembuatan larutan baku induk DPPH konsentrasi 100 ppm. Ditimbang sebanyak $10 \mathrm{mg}$ serbuk DPPH dimasukkan kedalam labu tentukur $100 \mathrm{ml}$ ditambahkan $n$-heksana hingga $100 \mathrm{ml}$, dikocok hingga homogen.

d. Pembuatan larutan DPPH konsentrasi 40ppm Dari larutan baku DPPH 100 ppm dipipet sebanyak $20 \mathrm{ml}$ dimasukkan kedalam labu terukur $50 \mathrm{ml}$ dan ditambahkan n-heksana sampai tanda batas, dikocok hingga homogen

e. Pengukuran absorbansi DPPH

Larutan DPPH 40 ppm dipipet sebanyak $2 \mathrm{ml}$ dimasukkan kedalam botol vial yang sudah dibungkus dengan alumunium foil dan ditambahkan $2 \mathrm{ml}$ n-heksana, dikocok dan didiamkan selama 30 menit selanjutnya, dimasukkan kedalam kuvet, kemudian diamati dengan spektrofotometer UV-Vis absorbansinya pada panjang gelombang maksimum

f. Pengukuran aktivitas peredaman radikal bebas Larutan DPPH 40 ppm dipipet sebanyak $2 \mathrm{ml}$ dimasukkan kedalam botol vial yang sudah dibungkus dengan alumunium foil dan ditambahkan $2 \mathrm{ml}$ larutan uji dari masing-masing konsentrasi, dikocok hingga homogen, kemudian didiamkan selama 30 menit. Setelah itu diamati absorbansinya pada gelombang maksimum dengan spektrofotometer UV-Vis. Hasil absorbansi tersebut dilakukan perhitungan presentase peredaman dengan rumus :

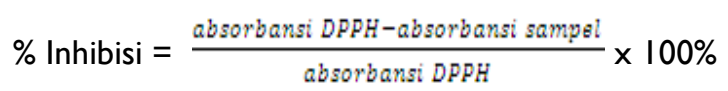

Keterangan :

Absorbansi kontrol = absorbansi DPPH

Absorbansi sampel $=$ absorbansi ekstrak uji + DPPH

\section{HASIL DAN PEMBAHASAN}

I. Determinasi Tanaman
Hasil determinasi tanaman yang dilakukan di Balai Konservasi Tumbuhan Kebun Raya "Eka Karya” Bali Lembaga Ilmu Penelitian Indonesia, Candikuning, Baturiti, Tabanan membuktikan bahwa benar tanaman yang digunakan dalam penelitian ini adalah tumbuhan Jeruk Bali dengan nama latin Citrus maxima (Burm.) Merr. berasal dari suku Rutaceae dan termasuk ke dalam keluarga Citrus.

2. Pembuatan Simplisia

Sebanyak 3100 gram kulit buah jeruk bali segar setelah dilakukan pengeringan menghasilkan simplisia kering dengan berat 889 gram.

3. Ekstraksi

Ekstraksi dilakukan dengan menggunakan metode maserasi selama 5 hari. Dari hasil maserasi sebanyak 250 gram serbuk simplisia kulit buah jeruk bali dalam beberapa kali replikasi diperoleh ekstrak kental sebanyak I,5 gram dengan persentase rendemen sebanyak $0,6 \%$.

4. Pemeriksaan organoleptis

Serbuk: bau khas kulit jeruk warna coklat muda rasanya pahit dan ekstrak kental, berwarna coklat tua, bau khas.

5. Skrining fitokimia

Tabel I. Hasil Skrining Fitokimia

\begin{tabular}{|c|c|c|}
\hline Senyawa & Pereaksi & Hasil Pengamatan \\
\hline Flavonoid & $\begin{array}{l}\text { Serbuk Mg dan } \\
\mathrm{HCl} \text { Pekat }\end{array}$ & $\begin{array}{ll}\text { Terbentuk } & \text { larutan } \\
\text { berwarna } & \text { merah } \\
\text { (Positif) } & \end{array}$ \\
\hline Alkaloid & $\begin{array}{l}\text { Dragendrof } \\
\text { Mayer }\end{array}$ & $\begin{array}{l}\text { Endapan jingga (positif) } \\
\text { Endapan Putih (positif) }\end{array}$ \\
\hline $\begin{array}{l}\text { Triterpenoid } \\
\text { dan steroid }\end{array}$ & $\begin{array}{l}\text { Kloroform }+ \text { asam } \\
\text { asetat anhidrat }+ \\
\text { asam sulfat pekat } \\
\text { melalui dinding } \\
\text { tabung }\end{array}$ & $\begin{array}{l}\text { Steroid Terbentuk } \\
\text { Cincin berwarna hijau } \\
\text { kebiruan (positif) } \\
\text { Triterpenoid } \\
\text { terbentuk cincin } \\
\text { kecoklatan (positif) }\end{array}$ \\
\hline Tanin & $\mathrm{FeCl}_{3} 10 \%$ & $\begin{array}{l}\text { Terbentuk warna } \\
\text { hitam } \\
\text { (positif) }\end{array}$ \\
\hline Saponin & Aquadest & $\begin{array}{l}\text { Timbul busa saat di } \\
\text { kocok tetapi perlahan } \\
\text { mengilang (negatif) }\end{array}$ \\
\hline
\end{tabular}


6. Hasil analisis Kromatografi Lapis Tipis

\section{a. Flavonoid}

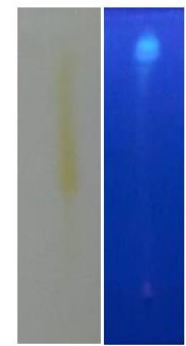

(a)

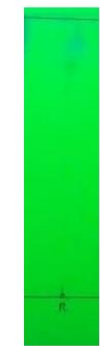

(b)

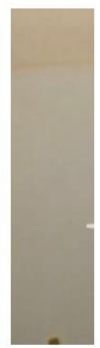

(d)

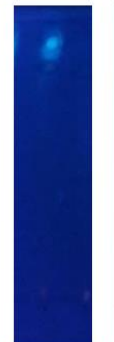

(e)

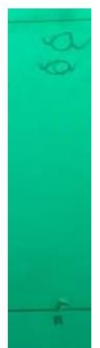

(f)
Keterangan gambar I : (a) pengamatan pada sinar tampak, (b) pengamatan pada sinar UV $365 \mathrm{~nm}$, (c) pengamatan pada sinar UV $254 \mathrm{~nm}$, (d) pengamatan pada sinar tampak setelah diuapkan dengan ammonia(e) pengamatan pada sinar UV $365 \mathrm{~nm}$ setelah diuapkan dengan ammonia, (f) pengamatan pada sinar UV $254 \mathrm{~nm}$ setelah diuapkan denganammonia.

Tabel 2. Nilai Rf Hasil Elusi Ekstrak dengan Fase gerak BAA $(4: 1: 5)$

\begin{tabular}{|c|c|c|c|c|c|}
\hline \multicolumn{3}{|c|}{ Sesudah Elusi } & \multicolumn{3}{|c|}{$\begin{array}{c}\text { Sesudah Diuapkan } \\
\text { Ammonia }\end{array}$} \\
\hline \multirow[t]{2}{*}{ Rf } & & UV (nm) & \multirow[t]{2}{*}{ Visual } & \multicolumn{2}{|c|}{ UV (nm) } \\
\hline & Visual & 254 & & 365 & 254 \\
\hline \multirow[t]{3}{*}{0,662} & Kuning Biru & Hitam & Kuning & Fluorens & Hitam \\
\hline & & & kehitaman & $\mathrm{i}$ & \\
\hline & & & & Biru & \\
\hline \multirow[t]{2}{*}{0,875} & Kuning Merah & & Kuning & Kuning & \\
\hline & & & kehitaman & $\begin{array}{l}\text { Kemera } \\
\text { han }\end{array}$ & \\
\hline
\end{tabular}

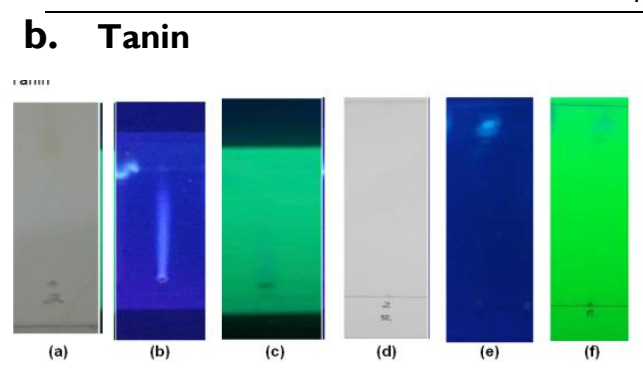

Keterangan gambar 2 : (a) pengamatan pada sinartampak, (b) pengamatan pada sinar UV $365 \mathrm{~nm}$, (c) pengamatan pada sinar UV $254 \mathrm{~nm}$, (d) pengamatan pada sinar tampak setelah disemprot denganFeCl , (e) pengamatan pada sinar UV $365 \mathrm{~nm}$ setelah disemprot dengan $\mathrm{FeCl}_{3}$, (f) pengamatan pada sinar UV $254 \mathrm{~nm}$ setelah disemprot denganFeCl $\mathrm{F}_{3}$

Tabel 3. Nilai Rf Hasil Elusi Ekstrak dengan Fase Gerak Metanol dan Air dengan Perbandingan (6:4)

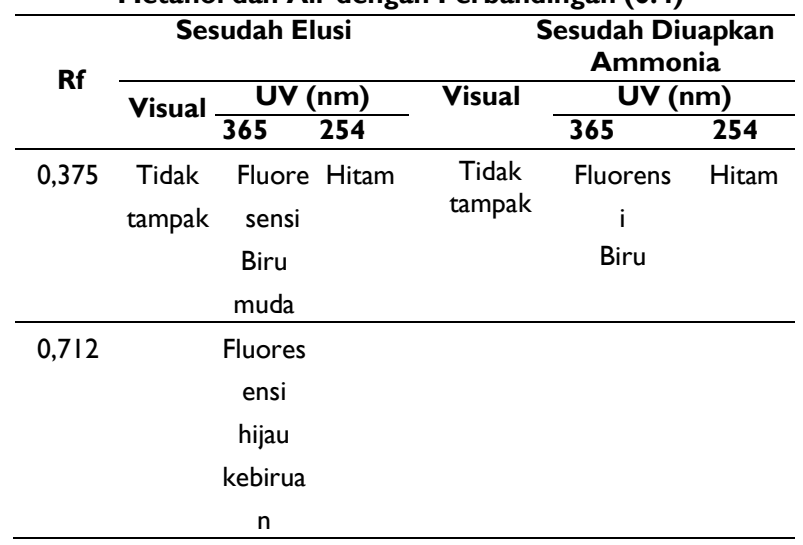

\section{c. Steroid}
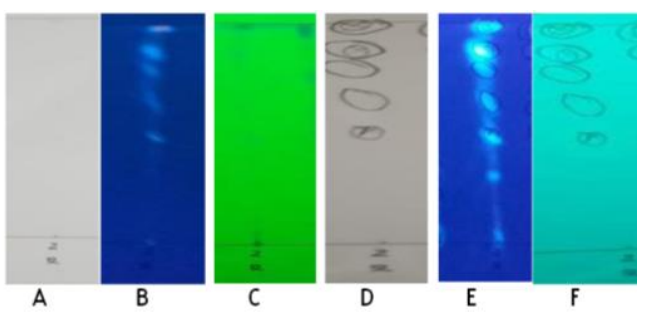

Keterangan gambar 3 : (a) pengamatan pada sinartampak, (b) pengamatan pada sinar UV $365 \mathrm{~nm}$, (c) pengamatan pada sinar UV $254 \mathrm{~nm}$, (d) pengamatan pada sinar tampak setelah disemprot dengan disemprot Liebermen Burchard, (e) pengamatan pada sinar UV $365 \mathrm{~nm}$ setelah disemprot Liebermen Burchard, (f) pengamatan pada sinar UV $254 \mathrm{~nm}$ setelah disemprot Liebermen Burchard.

Tabel 4. Nilai Rf Hasil Elusi Ekstrak dengan Fase Gerak

Kloroform dan Methanol dengan Perbandingan (9:I)

\begin{tabular}{|c|c|c|c|c|c|c|}
\hline \multirow{3}{*}{ Rf } & \multicolumn{3}{|c|}{ Sesudah Elusi } & \multicolumn{3}{|c|}{$\begin{array}{c}\text { Sesudah Diuapkan } \\
\text { Ammonia }\end{array}$} \\
\hline & \multirow{2}{*}{ Visual } & \multicolumn{2}{|c|}{ UV (nm) } & \multirow[t]{2}{*}{ Visual } & \multicolumn{2}{|c|}{ UV (nm) } \\
\hline & & 365 & 254 & & 365 & 254 \\
\hline 0,5 & kuning & $\begin{array}{c}\text { Biru } \\
\text { kemer } \\
\text { ahan }\end{array}$ & Hitam & Kuning & $\begin{array}{l}\text { Biru } \\
\text { muda }\end{array}$ & Hitam \\
\hline 0,637 & - & biru & - & - & - & - \\
\hline 0,787 & - & $\begin{array}{l}\text { Biru } \\
\text { muda }\end{array}$ & - & - & - & - \\
\hline 0,875 & - & $\begin{array}{l}\text { Biru } \\
\text { muda }\end{array}$ & Hitam & - & - & - \\
\hline $\mathrm{I}, 0$ & - & $\begin{array}{l}\text { Merah } \\
\text { kebiru }\end{array}$ & Hitam & - & - & - \\
\hline
\end{tabular}

\section{d. Saponin}

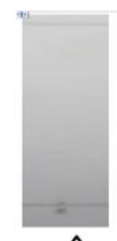

A
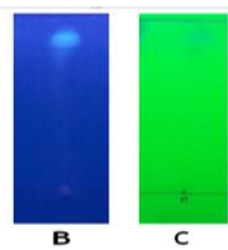
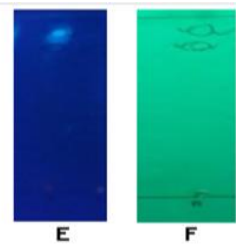

Keterangan gambar 4 : (a) pengamatan pada sinartampak, (b) pengamatan pada sinar UV $365 \mathrm{~nm}$, (c) pengamatan pada sinar UV254nm, (d) pengamatan pada sinar tampak setelah disemprot dengan anisaldehid-asam sulfat (e) pengamatan pada sinar UV 365 $\mathrm{nm}$ setelah disemprot anisaldehid-asam sulfat, (f) pengamatan pada sinar UV $254 \mathrm{~nm}$ setelah disemprot anisaldehid-asam sulfat

Tabel. 5. Nilai Rf Hasil Elusi Ekstrak Dengan Fase Gerak Kloroform, Methanol, Dan Air Dengan Perbandingan $(6,2: 4,8: 0,97)$

\begin{tabular}{|c|c|c|c|c|c|c|}
\hline \multicolumn{4}{|c|}{ Sesudah Elusi } & \multicolumn{3}{|c|}{$\begin{array}{c}\text { Sesudah Diuapkan } \\
\text { Ammonia }\end{array}$} \\
\hline \multirow[t]{2}{*}{ Rf } & \multirow{2}{*}{ Visual } & \multicolumn{2}{|c|}{ UV (nm) } & \multirow[t]{2}{*}{ Visual } & \multicolumn{2}{|c|}{ UV (nm) } \\
\hline & & 365 & 254 & & 365 & 254 \\
\hline 0,85 & Kuning & $\begin{array}{l}\text { Biru } \\
\text { muda }\end{array}$ & Hitam & Kuning & $\begin{array}{l}\text { Biru } \\
\text { muda }\end{array}$ & Hitam \\
\hline 0,93 & & $\begin{array}{l}\text { Biru } \\
\text { muda }\end{array}$ & & & $\begin{array}{l}\text { Biru } \\
\text { muda }\end{array}$ & \\
\hline
\end{tabular}




\section{e. Triterpenoid}
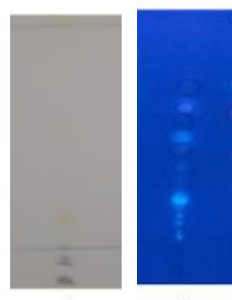

B

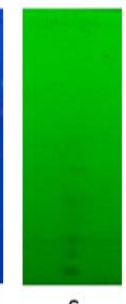

$c$

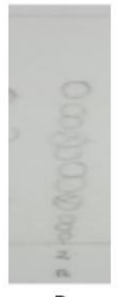

D

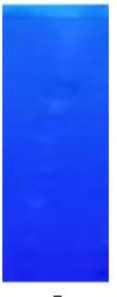

E

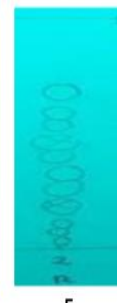

F
Keterangan gambar 5: (a) pengamatan pada sinar tampak (b) pengamatan pada sinar UV $365 \mathrm{~nm}$, (c) pengamatan pada sinar UV254nm, (d) pengamatan pada sinar tampak setelah disemprot dengan anisaldehid-asam sulfat (e) pengamatan pada sinar UV $365 \mathrm{~nm}$ setelah disemprot anisaldehid-asam sulfat, (f) pengamatan pada sinar UV $254 \mathrm{~nm}$ setelah disemprot anisaldehid-asam sulfat.

Tabel 6. Nilai Rf Hasil Elusi Ekstrak Dengan Fase Gerak NHeksana Dan Etil Asetat Dengan Perbandingan (16:4)

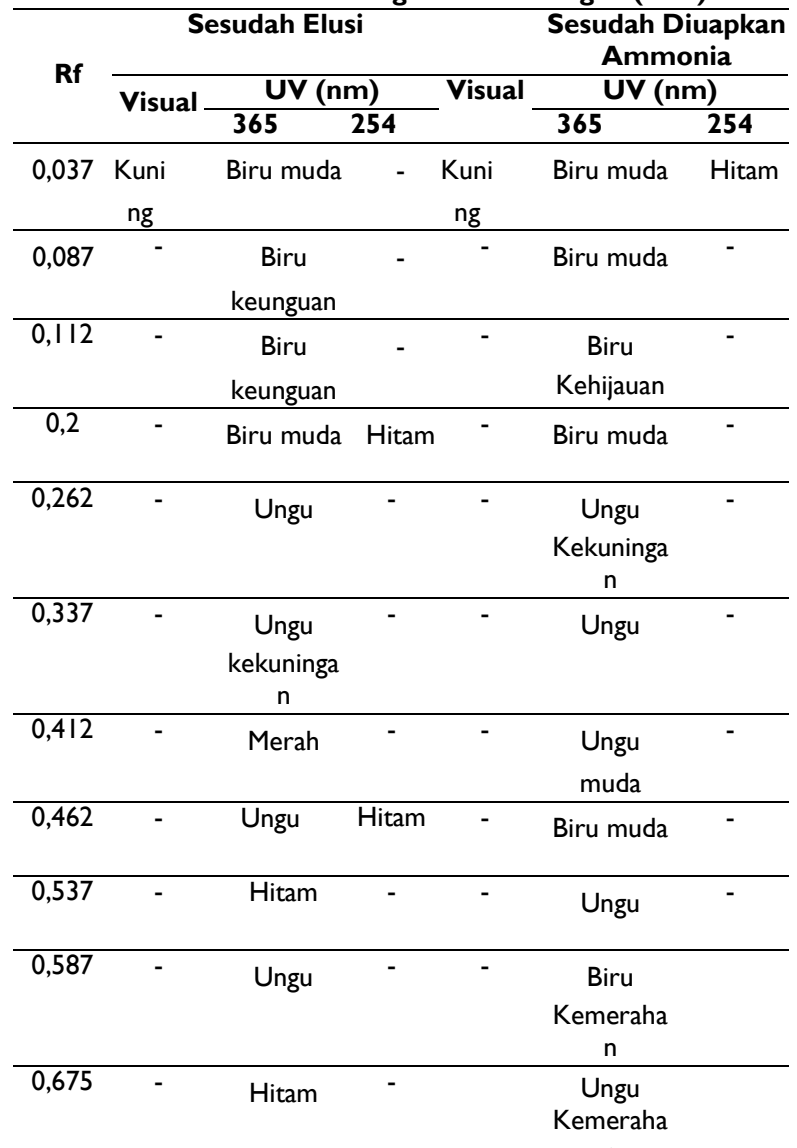

$n$

Tabel 7. Hasil pengujian menggunakan metode DPPH

\begin{tabular}{|c|c|c|c|}
\hline Sample & $\begin{array}{l}\text { Konsentrasi } \\
\text { ( ppm ) }\end{array}$ & Absorbansi & $\begin{array}{c}\% \\
\text { Peredaman }\end{array}$ \\
\hline \multirow{6}{*}{$\begin{array}{l}\text { Ekstrak } \\
\text { kulit buah } \\
\text { jeruk bali }\end{array}$} & 5 & 0,418 & 4,35 \\
\hline & 15 & 0,397 & 9,15 \\
\hline & 30 & 0,366 & 16,25 \\
\hline & 40 & 0,346 & 20,82 \\
\hline & 50 & 0,338 & 22,65 \\
\hline & $I C 50=1 \mathrm{I} I, 6$ & & \\
\hline \multirow[t]{6}{*}{ Trolox } & 5 & 0,306 & 29,98 \\
\hline & 15 & 0,229 & 47,60 \\
\hline & 30 & 0,120 & 72,54 \\
\hline & 40 & 0,062 & 85,81 \\
\hline & 50 & 0,035 & 91,99 \\
\hline & $\mathrm{IC} 50=17,04$ & & \\
\hline
\end{tabular}

Dari data presentase peredaman dibuat kurva regresi linier yang dapat dilihat pada gambar berikut :

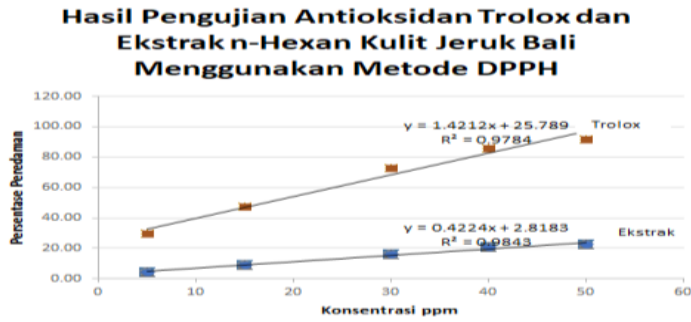

Gambar 6. Kurva Hasil Pengujian Antioksidan Trolox dan Ekstrak n-Hexan Kulit Jeruk Bali Menggunakan Metode DPPH

Sesuai dengan kurva diatas, terdapat hubungan antara konsentrasi sampel uji dengan presentase peredaman yaitu didapatkan persamaan regresi ekstrak $y=$ $0,4224 x+2.8183$, dengan nilai $R^{2}=0,9848$ dan trolox $y=1,4212 x+25.789$ dengan nilai $R^{2}=0,9784$. Dari persamaan tersebut dilakukan perhitungan $I_{50}$ dengan mengganti nilai $y=50$. Hasil yang diperoleh yaitu nilai $\mathrm{IC}_{50}$ ekstrak kulit jeruk bali adalah III,69 ppm dan $\mathrm{IC}_{50}$ trolox sebagai pembanding atau kontrol positif adalah 17,04 ppm.

\section{PEMBAHASAN}

Pemanfaatan kulit jeruk bali masih sangat terbatas di Indonesia sehingga perlu dilakukan kajian terkait cara pemanfaatan limbah kulit jeruk bali baik sebagai obat tradisional maupun sebagai kosmetik dan bahan makanan. Spesies genus citrus yang paling banyak tumbuh di daerah Bali adalah Citrus maxima atau jeruk bali. Jumlah limbah kulit jeruk bali saat ini semakin banyak namun tidak diimbangi dengan cara pengolahan dan pemanfaatannya.

Determinasi tanaman dilakukan untuk membuktikan kebenaran bahan yang digunakan pada penelitian. Identifikasi tanaman dilakukan di Balai Konservasi Tumbuhan Kebun Raya “Eka Karya” Bali Lembaga Ilmu Penelitian Indonesia, Candikuning, Baturiti, Tabanan. Hasil identifikasi diketahui bahwa tanaman yang digunakan adalah tumbuhan jeruk bali dengan nama latin Citrus maxima (Burm.) Merr berasal dari suku Rutaceae dan termasuk ke dalam keluarga Citrus. Kulit buah jeruk bali yang digunakan diperoleh dari kebun warga di Kabupaten Klungkung, dengan buah 
berbentuk bulat, warna hijau kekuningan. Simplisia hasil pengeringan dihaluskan untuk proses ekstraksi menggunakan metode maserasi. Metode maserasi merupakan metode penyarian yang sederhana, mudah, dan tanpa melalui proses pemanasan, sehingga kemungkinan rusaknya komponen senyawa kimia dapat diminimalisir. Pemilihan metode maserasi dikarenakan terdapat kandungan kimia yang ada didalam kulit buah jeruk bali (Citrus maxima Merr.) yang mudah rusak jika dilakukan pemanasan. Pada saat maserasi, konsentrasi lingkungan luar sel lebih tinggi daripada konsentrasi dalam sel, sehingga isi sel termasuk zat aktif atau metabolit sekunder yang terkandung di dalamnya akan keluar dan terlarut dalam pelarut (Yulianti et al., 20II). Keuntungan cara penyarian dengan maserasi adalah cara pengerjaan dan peralatan yang digunakan sederhana serta mudah diperoleh. Proses penyarian dilakukan dengan cara merendam sejumlah serbuk simplisia dalam cairan penyari. Cairan penyari akan menembus dinding sel dan masuk ke dalam rongga sel yang mengandung zat aktif. Zat aktif akan terlarut dalam cairan penyari kemudian akan terdesak keluar sel dikarenakan adanya perbedaan konsentrasi antara larutan zat aktif dengan cairan di luar sel. Peristiwa tersebut berlangsung terus menerus hingga terjadi keseimbangan antara larutan di luar sel dan di dalam sel (Dianingati et al., 2013).

Ekstraksi menggunakan pelarut $n$-hexan dengan mempertimbangkan apakah dengan menggunakan pelarut non polar senyawa aktif yang terkandung dalam kulit jeruk bali dapat tersari. Selain itu $n$-heksana dimanfaatkan sebagai pelarut karena sifatnya yang inert, tidak bereaksi dengan komponen yang akan diekstraksi (Kristanti, 2008). Pelarut $n$-heksana biasa digunakan untuk mengekstrak minyak dan lemak yang memiliki kepolaran yang sama (Aziz et al., 20I5). Pelarut $n$-heksana merupakan salah satu pelarut yang baik untuk mengekstraksi senyawa-senyawa yang bersifat non polar. Hasil rendemen ekstrak yang dihasilkan sebesar $0,6 \%$. Beberapa faktor yang diperkirakan mempengaruhi hasil rendemen adalah metode ekstraksi yang digunakan, ukuran partikel sampel, kondisi dan waktu penyimpanan, lama waktu ekstraksi, perbandingan jumlah sampel terhadap jumlah pelarut yang digunakan dan jenis pelarut yang digunakan (Salamah et al., 2008). Proses penarikan bahan (ekstraksi) terjadi dengan mengalirnya bahan pelarut ke dalam sel yang menyebabkan protoplasma membengkak, dan bahan yang terkandung dalam sel akan terlarut sesuai dengan kelarutannya (Voight, 1995 ). Daya melarutkan yang tinggi ini berhubungan dengan kepolaran pelarut dan kepolaran senyawa yang diekstraksi. Tumbuhan mengandung banyak senyawa fenolik, senyawa fenolik ini memiliki sifat yang cenderung larut dalam pelarut polar (Harbone, 1987). Hasil pemeriksaan organoleptik dari serbuk kulit buah jeruk bali diperoleh serbuk kulit buah jeruk bali berbentuk serbuk, berwarna coklat muda, rasa pahit dan berbau khas jeruk. Ekstrak yang diperoleh berbentuk kental biasanya disebabkan karena adanya kandungan air antara 20-25\% pada ekstrak (Depkes RI, 1995). Warna coklat tua pada ekstrak kulit buah jeruk bali dikarenakan kulit buah jeruk bali mengandung senyawa flavonoid. Flavonoid teroksidasi oleh oksigen sehingga warna produk menjadi coklat (Rejeki et al., 2012). Rasa pahit pada ekstrak kulit buah jeruk bali dikarenakan adanya kandungan senyawa tanin. Senyawa tanin menyebabkan rasa sepat ketika dikonsumsi karena terbentuknya ikatan silang antara tanin dan protein di rongga mulut (Ajeng \& Asngad, 2016). Bau khas dari ekstrak kulit buah jeruk bali berasal dari senyawa limonen dan minyak aktsiri yang memberikan bau khas pada ekstrak kulit buah jeruk bali (Yustinah, 2016).

Pada identifikasi flavonoid menggunakan uji wilstater yaitu penambahan serbuk magnesium dan $\mathrm{HCl}$ pekat pada ekstrak. Penambahan serbuk magnesium dan asam klorida pada pengujian flavonoid akan menyebabkan tereduksinya senyawa flavonoid yang ada sehingga menimbulkan reaksi warna merah yang 
merupakan ciri adanya flavonoid (Robinson, 1983). Magnesium dan asam klorida bereaksi membentuk gelembung-gelembung yang merupakan gas $\mathrm{H}_{2}$, sedangkan logam $\mathrm{Mg}$ dan $\mathrm{HCl}$ pekat pada uji ini berfungsi untuk mereduksi inti benzopiron yang terdapat pada struktur flavonoid sehingga terbentuk perubahan warna menjadi hijau (Prashant, 20II). Flavonoid merupakan senyawa polifenol yang banyak terdapat dalam tumbuh-tumbuhan. Untuk mengetahui kandungan flavonoid maka dilakukan Uji wilstater sianidin, jika terjadi perubahan warna maka positif mengandung flavonoid (Harbone, 1987). Pada skrining identifikasi saponin menggunakan uji forth dengan melihat terbentuknya busa dan dapat bertahan selama 10 menit. Timbulnya busa pada uji forth menunjukkan adanya saponin yang mempunyai kemampuan membentuk buih dalam air yang terhidrolisis menjadi glukosa dan senyawa lainnya (Marliana et al., 2005). Hasil pada pengujian saponin tidak terbentuk busa.

Pada identifikasi kandungan senyawa alkaloid melalui reaksi tabung ekstrak dan serbuk kulit jeruk bali memberikan hasil positif. Prinsip dasar reaksi ini adalah reaksi pengendapan dimana terjadi pergantian ligan. Atom nitrogen yang mempunyai pasangan elektron bebas pada alkaloid dapat mengganti ion iodo dalam pereaksi-pereaksi. Pereaksi dragendorff mengandung bismut nitrat dan kalium iodida dalam larutan asam asetat glasial (kalium tetraiodobismutat (III)) sedangkan pereaksi mayer mengandung kalium iodida dan merkuri klorida (kalium tetraiodomerkurat (II)). Hasil positif alkaloid pada uji mayer ditandai dengan terbentuknya endapan putih. Diperkirakan endapan tersebut adalah kompleks kalium-alkaloid. Pada pembuatan pereaksi mayer, larutan mercuri (II) klorida ditambah kalium iodida akan membentuk endapan merah mercuri (II) iodida. Jika kalium iodida yang ditambahkan berlebih maka akan terbentuk kalium tetraiodomerkurat(II) (Shevla, 1985 ). Alkaloid mengandung atom nitrogen yang mempunyai pasangan elektron bebas sehingga dapat digunakan untuk membentuk ikatan kovalen koordinat dengan ion logam (Malangingi et al., 20/2)(Sangi et al., 2019). Pada uji alkaloid dengan pereaksi Mayer, diperkirakan nitrogen pada alkaloid akan bereaksi dengan ion logam $\mathrm{K}+$ dari kalium tetraiodomerkurat (II) membentuk kompleks kaliumalkaloid yang mengendap.

Pada pengujian steroid dan triterpenoid, analisis senyawa didasarkan pada kemampuan senyawa tersebut membentuk warna dengan $\mathrm{H}_{2} \mathrm{SO}_{4}$ pekat dalam pelarut anhidirid asam asetat (Sangi et al., 2019). Hasil yang diperoleh menunjukkan hasil positif dengan terbentuknya cincin berwarna biru kehijauan mengandung senyawa steroid dan cincin berwarna kecoklatan yang menunjukkan kandungan triterpenoid. Pada skrining tanin, pereaksi besi (III) klorida digunakan secara luas untuk mengidentifikasi senyawa tanin. Pengujian tanin dilakukan dengan melakukan penambahan $\mathrm{FeCl}_{3} \quad 10 \%$ diperkirakan akan menimbulkan warna biru tua, biru kehitaman atau hitam kehijauan (Malangngi et al., 20I2). Hasil yang diperoleh pada ekstrak kulit jeruk Bali adalah terbentuknya warna hijau kehitaman. Terbentuknya warna hijau pada ekstrak setelah ditambah $\mathrm{FeCl}_{3} \quad 10 \%$ karena tannin akan bereaksi dengan ion $\mathrm{Fe}^{3+}$ membentuk senyawa kompleks (Harbone, 1987).

Saponin merupakan senyawa yang mempunyai gugus hidrofilik dan hidrofobik. Saponin pada saat digojok terbentuk buih karena adanya gugus hidrofil yang berikatan dengan air sedangkan hidrofob akan berikatan dengan udara. Pada struktur misel, gugus polar menghadap ke luar sedangkan gugus non-polar menghadap ke dalam. Keadaan ini yang membentuk busa, namun dalam analisis ini sampel tidak memiliki saponin karena tidak memiliki kemampuan untuk membentuk busa (Sangi et al., 2019).

Untuk mempertegas hasil skrining pengujian dilanjutkan dengan analisis kromatografi lapis tipis $(\mathrm{KLT})$, meliputi senyawa flavonoid, tannin, saponin, dan terpenoid/steroid. Deteksi bercak KLT dapat diihat secara fisika pada lampu UV 254 nm dan 365 nm 
dan secara kimia dengan menggunakan pereaksi semprot. Pada lampu UV 254 nm, lempeng akan berfluoresensi sedangkan sampel akan tampak berwarna gelap/hitam. Penampakan noda pada lampu UV $254 \mathrm{~nm}$ dan $365 \mathrm{~nm}$ adalah karena adanya daya interaksi antara sinar UV dengan indikator fluoresensi yang terdapat pada lempeng. Fluoresensi cahaya yang tampak merupakan emisi cahaya yang dipancarkan oleh komponen tersebut ketika elektron yang tereksitasi dari tingkat energi dasar ke tingkat energi yang lebih tinggi kemudian kembali ke keadaan semula sambil melepaskan energi. Selain itu, nilai Rf juga ditentukan, dimana nilai Rf dapat dijadikan bukti dalam identifikasi senyawa. Bila nilai Rf memiliki nilai yang sama maka senyawa tersebut dapat dikatakan memiliki karakteristik yang sama atau mirip dengan pembandingnya. Namun pada penelitian ini tidak menggunakan pembanding sehingga pembuktiannya berdasarkan kajian literature. Nilai Rf merupakan perbandingan jarak yang ditempuh eluen dan fase gerak pada plat KLT. Nilai Rf digunakan sebagai nilai perbandingan relatif antar sampel. Senyawa yang memiliki Rf yang lebih besar berarti memiliki kepolaran yang rendah, begitu juga sebaliknya. Jika Rf terlalu tinggi, maka kepolaran eluen harus dikurangi. Sebaliknya jika Rf terlalu rendah maka kepolaran eluen harus ditambah (Gandjar \& Rohman, 2007). Identifikasi suatu senyawa dapat dilihat dari nilai Rf dimana jika suatu senyawa polar akan mempunyai hRf kecil dan senyawa non-polar akan menghasilkan hRf besar

Uji KLT pada senyawa flavonoid menggunakan fase diam Silika $G_{60} F_{254}$ dengan fase gerak menggunakan fase gerak n-butanol : asam asetat glasial : air (4:1:5) terdapat 2 spot warna pada $\operatorname{Rf} 0,662,0,875$. Berdasarkan hubungan antara bercak warna dengan senyawa flavonoid dapat dilihat pada warna yang dihasilkan yang terlihat pada sinar UV dan diperkuat dengan reaksi penyemprot menggunakan uap ammonia. Pada umumnya jika diamati menggunakan sinar UV senyawa flavonoid akan memberikan warna ungu gelap, fluorensi biru muda, dan tidak nampak. Pada sinar UV $365 \mathrm{~nm}$ terdapat spot warna merah pada Rf 0,875. Setelah penguapan dengan amonia dengan sinar UV pada panjang gelombang $365 \mathrm{~nm}$ terbentuk noda yang berwarna kuning kemerahan. Hal ini sesuai dengan penelitian Ghosal dan Mandal (2012) yang menyatakan bahwa nilai $\operatorname{Rf}$ 0,85-0,87 diasumsikan sebagai senyawa flavonoid karena menunjukkan warna merah dan berfluoresensi kuning setelah dihidrolisis, senyawa yang diduga adalah flavonol. Aktivitas sebagai antioksidan dimiliki oleh sebagian besar flavonoid karena adanya gugus hidroksi fenolik dalam struktur molekulnya (Hakim et al., 2017). Senyawa flavonoid jenis flavonol akan berfluoresensi kuning, kuning redup atau jingga apabila diamati pada sinar UV 365 nm (Marliana et al., 2005). $\mathrm{Hal}$ ini menunjukan adanya senyawa flavonoid dalam ekstrak kulit buah jeruk bali.

Identifikasi tanin pada ekstrak kulit buah jeruk bali dengan menggunakan fase gerak metanol dan air dengan perbandingan (6:4) diperoleh 2 spot yaitu dengan Rf 0,375, 0,7I25. Pada UV $365 \mathrm{~nm}$ terbentuk noda berwarna fluorensi hijau kebiruan, dengan nilai Rf 0,7I25 setelah disemprot $\mathrm{FeCl}_{3} 3 \%$ dalam etanol terbentuk spot noda fluorensi biru pada UV $365 \mathrm{~nm}$, hal ini menunjukkan adanya senyawa golongan tannin. Senyawa tannin dapat dilihat dari bercak biru kehitaman yang dihasilkan setelah disemprot dengan $\mathrm{FeCl} 3$ 5\%. Tannin merupakan senyawa yang berpotensi sebagai antioksidan (Banu \& Nagarajan, 2014).

KLT triterpenoid ekstrak kulit buah jeruk bali dengan menggunakan fase gerak $n$-heksana dan etil asetat dengan perbandingan (16:4) diperoleh 5 spot noda dengan kemungkinan $\operatorname{Rf}$ 0,5 merupakan golongan triterpeoind karena setelah penyemprotan dengan pereaksi Liebermann burchard memberikan warna biru muda agak kehijauan di sinar UV 365 dan UV 254 membentuk warna kuning. Reaksi positif ditandai 
dengan adanya noda berwarna hijau biru (Kristanti, 2008 ).

Pada identifikasi senyawa saponin ekstrak kulit buah jeruk bali dengan menggunakan fase gerak kloroform, methanol, dan air dengan perbandingan (6,2 : 4,8 : 0,97). Pada sinar UV $365 \mathrm{~nm}$ terbentuk spot noda berwarna biru muda, dengan nilai $\mathrm{Rf}$ 0,85 disemprot penampak noda Anisaldehid-asam sulfat terbentuk spot noda biru muda pada sinar UV dengan panjang gelombang $365 \mathrm{~nm}$. Saponin jika dideteksi dengan pereaksi semprot anisaldehid-asam sulfat akan memberikan warna biru sampai biru violet terkadang berupa bercak warna merah, kuning, biru tua, ungu, hijau, atau berupa kuning coklat pada sinar tampak. Saponin tanpa perlakuan kimia (pereaksi semprot) di bawah sinar UV $254 \mathrm{~nm}$ tidak terjadi pemadaman bercak dan di bawah sinar UV $365 \mathrm{~nm}$ bercak tidak berfluorosensi (Wagner \& Bladt, 1996). Dari hasl KLT yang nampak adalah bercak biru agak muda sehingga kemungkinan tidak mengandung saponin.

Uji aktivitas antioksidan secara kuantitatif menggunakan metode DPPH dipilih karena ujinya sederhana, mudah, cepat dan peka serta hanya memerlukan sedikit sampel (Hanani, 20l4). Kelemahan dari metode ini adalah radikal DPPH hanya dapat dilarutkan dalam media organik, tidak pada media yang bersifat air sehingga membatasi kemampuannya dalam penentuan peran antioksidan hidrofilik. Prinsip dari metode ini adalah adanya donasi atom hidrogen $(\mathrm{H}+)$ dari substansi yang diujikan kepada radikal DPPH menjadi senyawa non radikal difenil pikril hidrazin yang akan ditunjukkan oleh perubahan warna. Perubahan warna yang terjadi adalah perubahan warna dari ungu menjadi kuning, di mana intensitas perubahan warna DPPH berbanding lurus dengan aktivitas antioksidan untuk meredam radikal bebas tersebut (Molyneux, 2004). Pengukuran aktivitas antioksidan sampel dilakukan pada panjang gelombang $508 \mathrm{~nm}$ yang merupakan panjang gelombang maksimum DPPH. Adanya aktivitas antioksidan dari sampel mengakibatkan terjadinya perubahan warna pada larutan DPPH dalam metanol yang semula berwarna ungu pekat menjadi kuning pucat (Permana et al.,2003). Pengujian dilakukan pada panjang gelombang maksimum, karena pada panjang gelombang maksimum kepekaanya juga maksimal dan perubahan absorbansi untuk setiap satuan konsentrasi adalah paling besar dan disekitar panjang gelombang maksimal, bentuk kurva absorbansi datar dan pada kondisi tersebut hukum Lambert-Berr akan terpenuhi (Gandjar \& Rohman, 2007). Persamaan regresi yang diperoleh dari grafik hubungan antara konsentrasi ekstrak n-heksana kulit buah jeruk bali dengan persen penghambatan DPPH digunakan untuk mencari nilai $\mathrm{IC}_{50}$

Besarnya aktivitas antioksidan ditandai dengan nilai $I_{50}$, yaitu konsentrasi larutan sampel yang dibutuhkan untuk menghambat 50\% radikal bebas DPPH (Regina et al., 2008). Semakin kecil nilai $I C_{50}$ maka aktivitas peredaman radikal bebas semakin baik (Molyneux, 2004). Uji aktivitas antioksidan atau penghambatan terhadap radikal bebas menggunakan metode DPPH menunjukkan bahwa ekstrak $n$-hexan kulit buah jeruk bali (Citrus maxima Merr.) memiliki aktivitas sebagai antioksidan kategori sedang. Adanya aktivitas antioksidan pada kulit buah jeruk bali karena kaya adanya kandungan senyawa flavonoid, alkaloid, terpenoid/steroid, saponin dan tannin (Suryanita et al., 2019). Kontrol positif yang digunakan pada penelitian ini adalah trolox.Trolox merupakan antioksidan yang larut dalam air. Penggunaan kontrol positif pada pengujian aktivitas antioksidan ini adalah untuk mengetahui seberapa kuat potensi antioksidan yang ada pada ekstrak kulit buah jeruk bali jika dibandingkan dengan trolox. Apabila nilai $I_{50}$ sampel sama atau mendekati nilai $I C_{50}$ kontrol positif maka dapat dikatakan bahwa sampel berpotensi sebagai salah satu alternatif antioksidan yang sangat kuat.

Berdasarkan grafik dapat dilihat bahwa kurva kalibrasi dengan persamaan regresi untuk serapan pembanding 
troloks pada konsentrasi 5, I5, 30, 40 dan 50 ppm sebesar $y=1,4212 x+25,78$ dan pada ekstrak kulit buah jeruk bali diperoleh persamaan regresi $y=$ $0,4224 x+2,8183$ dan diperoleh hubungan yang linier antara serapan dengan konsentrasi. Persamaan regresi linear nilai b yang positif, menunjukkan bahwa kurva nilai penghambatan antioksidan terjadi peningkatan. Koefisien $b$ merupakan koefisien arah regresi linear dan menyatakan perubahan rata- rata variabel y untuk setiap perubahan variabel $x$ sebesar satu unit (Sudjana, 1996). Pada pengukuran serapan pembanding troloks yang ditunjukkan dengan nilai koefisien korelasi (R) sebesar 0,9784 dan serapan ekstrak kulit buah jeruk bali ditunjukkan dengan nilai koefisien (R) sebesar 0,9843 (R) ini mendekati angka I yang menunjukkan bahwa persamaan regresi tersebut adalah linier.

Berdasarkan persamaan regresi linier tersebut dapat ditentukan nilai IC $_{50}$ sebesar III,69 ppm. Nilai-nilai $I_{50}$ ini menunjukkan bahwa ekstrak tersebut memiliki aktivitas antioksidan kategori sedang, karena memiliki nilai $I_{50}$ antara $100-150 \mu \mathrm{g} / \mathrm{ml}($ Blois, 1958). Menurut Cockell dan Knowland (1999) suatu senyawa dikatakan sebagai peredam radikal bebas atau antioksidan yang sangat kuat jika nilai $I_{50}$ kurang dari 50 ppm kuat (50 ppm- I00 ppm), sedang ( 100 ppm- I 50 Ppm), dan lemah (I50 ppm-200 ppm). Berdasarkan hasil yang diperoleh, ekstrak kulit buah jeruk bali (Citrus maxima Merr.) menunjukkan aktivitas antioksidan kategori sedang. Akan tetapi apabila dibandingkan dengan aktivitas antioksidan senyawa pembanding yaitu Trolox yang memiliki nilai $I_{50} \quad$ I7,04 Ppm, aktivitas antioksidan ekstrak kulit buah jeruk bali (Citrus maxima Merr.) masih lebih rendah.

Aktivitas penghambatan radikal bebas DPPH ekstrak $n$ hexan kulit jeruk bali (Citrus maxima Merr.) ditentukan oleh berbagai senyawa antioksidan yang terdapat pada tumbuhan tersebut. Berdasarkan skrining fitokimia menunjukkan bahwa ekstrak kulit buah jeruk bali (Citrus maxima Merr.) mengandung flavonoid yang diduga memiliki aktivitas antioksidan. Kulit buah jeruk bali (Citrus maxima Merr.) mengandung senyawa flavonoid yaitu naringin dan hesperidin (Choi et al., 2007). Hal ini dibuktikan berdasarkan penelitian yang dilakukan terhadap kandungan ekstrak kulit jeruk bali dengan metode kromatografi lapis tipis, terlihat bahwa kandungan senyawa flavonoid yang terkandung dalam ekstrak kulit buah jeruk bali (Citrus maxima Merr.) yaitu rutin, naringin, dan hesperidin (Dianingati et al., 2013).

Senyawa flavonoid pada strukturnya mengandung gugus hidroksil yang dapat mendonorkan atom hidrogennya kepada radikal bebas, sehingga senyawa flavonoid berpotensi sebagai antioksidan. Flavonoid merupakan senyawa pereduksi yang dapat menghambat banyak reaksi oksidasi. Flavonoid memiliki kemampuan sebagai antioksidan karena mampu mentransfer sebuah elektron kepada senyawa radikal bebas, dimana $R \cdot$ merupakan senyawa radikal bebas, $\mathrm{Fl}-\mathrm{OH}$ merupakan senyawa flavonoid sedangkan $\mathrm{Fl}-\mathrm{OH} \cdot$ merupakan radikal flavonoid (Middleton et al, 2000). Antioksidan flavonoid bekerja dengan menekan pembentukan spesies oksigen reaktif dengan menghambat kerja enzim maupun dengan mengikat unsur-unsur yang terlibat dalam produksi radikal bebas, peredaman spesies oksigen reaktif, melindungi antioksidan tubuh(Kumar \& Pandey, 2013).

Ekstrak kulit buah jeruk bali (Citrus maxima Merr.) menunjukkan aktivitas antioksidan kategori sedang. Beberapa faktor yang mempengaruhi peranan ekstrak sebagai antioksidan salah satunya adalah jenis pelarut yang digunakan saat ekstraksi. Pelarut non polar cenderung menarik senyawa yang memiliki sifat non polar sehingga kemungkinan senyawa polar yang terkandung didalam kulit jeruk bali tidak dapat tersari secara maksimal.

Faktor kedua yang menyebabkan aktivitas antioksidan kategori sedang, karena senyawa flavonoid dalam ekstrak kulit buah jeruk bali adalah senyawa flavonoid masih dalam bentuk ekstrak murni dan bukan dalam bentuk isolatnya sehingga senyawa flavonoid yang 
terdapat dalam ekstrak kemungkinan masih berikatan dengan gugus glikosida dimana gugus glikosida yang berikatan dengan flavonoid dapat menurunkan aktivitas antioksidan. Aktivitas antioksidan akan meningkat dengan bertambahnya gugus hidroksil dan akan menurun dengan adanya gugus glikosida (Fukumoto \& Mazza, 2000). Senyawa flavonoid di alam umumnya sangat jarang ditemukan dalam bentuk aglikon flavonoid. Flavonoid dalam tumbuhan sering terdapat sebagai glikosida (flavonoid glikosida) dan jarang sekali ditemukan dalam bentuk tunggal/ aglikon flavonoid, oleh karena itu untuk menganalisis flavonoid lebih baik untuk menghidrolisis glikosida yang terikat pada flavonoid tersebut sebelum memperhatikan kerumitan glikosida yang mungkin terdapat dalam ekstrak asal (Harbone, 1987). Berdasarkan hasil reaksi skrining fitokimia, dimana setelah dilakukan pengujian wilstater dengan menggunakan $\mathrm{HCl}$ dan $\mathrm{Mg}$, ekstrak yang semula berwarna ungu kemudian berubah warna menjadi warna merah tua setelah pengujian wilstater tersebut.Warna asal ekstrak yang semula berwarna ungu diduga masih mengandung gugus glikosida sedangkan warna merah ekstrak setelah dilakukan uji wilstater menandakan bahwa senyawa flavonoid dalam ekstrak sudah berada dalam bentuk aglikonnya. Adanya gugus $\mathrm{OH}$ yang termetilasi atau terikat dengan glikosida, menyebabkan flavonoid tersebut tidak dapat teridentifikasi dengan pereaksi yang bersifat basa seperti $\mathrm{Mg}$, amoniak, $\mathrm{NaOH}, \mathrm{AlCl} 3$, dan sitroborat (Robinson, 1983). Untuk itu perlu dilakukan hidrolisis glikosida dari flavonoid glikosida. Mekanisme reaksi hidrolisis glikosida dari flavonoid yang mungkin terjadi pada pengujian wilstater dengan menggunakan reagen $\mathrm{HCl}$ dan $\mathrm{Mg}$. Penambahan $\mathrm{HCl}$ bertujuan untuk menghidrolisis flavonoid menjadi aglikon flavonoid dengan cara menghidrolisis o-glikosil. Glikosil yang terhidrolisis ini akan tergantikan dengan atom $\mathrm{H}+$ dari asam yang memiliki sifat ke-elektronegatifan yang kuat. Serbuk Mg yang ditambahkan menghasilkan senyawa kompleks yang berwarna merah. Ion magnesium ini diduga akan berikatan dengan senyawa flavonoid yang terdapat pada ekstrak sehingga muncul larutan yang berwarna merah.

Faktor ketiga yang menyebabkan aktivitas antioksidan ekstrak kulit buah jeruk bali dalam kategori sedang yaitu diduga senyawa yang terkandung didalam ekstrak kulit buah jeruk bali kemungkinan adalah flavonoid golongan flavonon. Dugaan bahwa terdapat senyawa flavonon didalam ekstrak kulit buah jeruk bali ini berdasarkan hasil skrining fitokimia dari ekstrak kulit buah jeruk bali. Senyawa flavonon memiliki ciri khas berwarna merah kuat bila direaksikan dengan $\mathrm{Mg} / \mathrm{HCl}$ (Harbone, 1987). Senyawa flavonon pada umumnya memiliki aktivitas antioksidan yang lemah (Burda \& Olezek, 200I). Faktor yang menyebabkan lemahnya aktivitas antioksidan pada senyawa flavonon pada umumnya disebabkan oleh gugus hidroksil yang terdapat pada struktur senyawa flavonon hanya sedikit dan pada cincin $\mathrm{C}$ flavonon tidak memiliki ikatan ganda pada ikatan 2-3 gugus 4-okso, sehingga kemungkinan besar untuk menstabilkan struktur senyawanya yang kehilangan elektron dari proses donor hidrogen dalam struktur senyawa flavonon tidak terjadi dengan demikian senyawa golongan flavonon pada umumnya memiliki potensi aktivitas antioksidan yang lemah.

\section{KESIMPULAN}

Kesimpulan dari penelitian diatas adalah:

Ekstrak $n$-hexan kulit buah jeruk bali (Citrus Maxima Merr.) mengandung senyawa metabolit sekunder berupa flavonoid, alkaloid, tanin, steroid dan triterpenoid.

Ekstrak $n$-hexan kulit buah jeruk bali (Citrus Maxima Merr.) memiliki aktivitas antioksidan secara spektrofotometri UV-Vis dengan nilai $I_{50}$ sebesar 111,69 ppm dan pada trolox 17,04 ppm sebagai pembanding. Ekstrak kulit buah jeruk bali dikategorikan sebagai antioksidan sedang. 


\section{UCAPAN TERIMA KASIH}

Ucapan terima kasih kepada seluruh sivitas akademika STF Mahaganesha, laboran dan seluruh pihak yang turut serta terlibat aktif dalam membantu proses penelitian dari awal hingga selesainya penelitian ini.

\section{REFERENSI}

I. Andriani Y. 2007. Uji Aktivitas Antioksidan Ekstrak Betaglukan Dari Saccharomyces Cerevisiae. Gradien [Internet]. 3(I):226-30.

2. Onkar, P., Bangar, J., \& Karodi, R. 2012. Evaluation of Antioxidant activity of traditional formulation Giloy satva and hydroalcoholic extract of the Curculigo orchioides Gaertn. Journal of Applied Pharmaceutical Science, 2(7), 29.

3. Kuntorini, E. M., Astuti M. D. 2010. Penentuan Aktivitas Antioksidan Ekstrak Etanol Bulbus Bawang Dayak (Eleutherine americana Merr.). Sains Dan Terapan Kimia. Volume. 4(I), I5-22.

4. Winarsi, H. 2007. Antioksidan alami dan radikal. Kanisius.

5. Astuti, S. 2012. Isoflavon kedelai dan potensinya sebagai penangkap radikal bebas. Jurnal Teknologi \& Industri Hasil Pertanian, I3(2), I26-I36.

6. Tristantini, D., Ismawati, A., Pradana, B. T., \& Jonathan, J. G. 2016. Pengujian aktivitas antioksidan menggunakan metode DPPH pada daun tanjung (Mimusops elengi L). In Seminar Nasional Teknik Kimia Kejuangan (p. I).

7. Halliwell, B. 1994. Free radicals and antioxidants: a personal view. Nutrition reviews, 52(8), 253-265.

8. Ergina, E., Nuryanti, S., \& Pursitasari, I. D. 2014. Uji kualitatif senyawa metabolit sekunder pada daun palado (Agave angustifolia) yang diekstraksi dengan pelarut air dan etanol. Jurnal Akademika Kimia, 3(3), I65-I72.

9. Atun, S. 2005. Pengembangan Potensi Bahan Alam sebagai Sumber Penemuan Obat Baru. Makalah disajikan dalam Seminar Nasional Kimia, Universitas Negeri Yogyakarta, Yogyakarta, 24 September

10. Zuhra, C. F., Tarigan, J. B., \& Sihotang, H. 2008. Aktivitas antioksidan senyawa flavonoid dari daun katuk (Sauropus androgunus (L) Merr.). Jurnal
Biologi Sumatera, 3(I), 7-I0.

II. Rafsanjani, M. K., \& Putri, W. D. R. 2014. Karakterisasi Ekstrak Kulit leruk Bali Menggunakan Metode Ultrasonic Bath (Kajian Perbedaan Pelarut Dan Lama Ekstraksi) [In Press September 2015].Jurnal Pangan dan Agroindustri, 3(4).

I2. Choi, S. Y., Ko, H. C., Ko, S. Y., Hwang, J. H., Park, I. G., Kang, S. H., ... \& Kim, S. I. 2007. Correlation between flavonoid content and the NO production inhibitory activity of peel extracts from various citrus fruits. Biological and Pharmaceutical Bulletin, 30(4), 772-778.

13. Dianingati, R. S., Novarina, A., Hana, A. K., \& Muntafi'ah, L. 20I3. December). Fortifikasi Ekstrak Kulit leruk Bali Pada Susu Tinggi Kalsium: Terobosan Baru Dalam Pengatasan Osteoporosis Pada Wanita Menopause, Teruji in Vivo Dan Molecular Docking. In Pekan Ilmiah Mahasiswa Nasional Program Kreativitas Mahasiswa-Penelitian 2013. Indonesian Ministry of Research, Technology and Higher Education.

14. Farnsworth, N. R.1966. Biological and phytochemical screening of plants. Journal of pharmaceutical sciences, 55(3), 225-276.

I5. Marliana, S. D., Suryanti, V., Suyono. 2005, Skrining Fitiokimia dan Analisis Kromatografi Lapis Tipis Komponen Kimia Buah Labu Siam (Sechium edule jacq. Swartz.) dalam Ekstrak Etanol, FMIPA, Universitas Sebelas Maret (UNS), Surakarta

16. Putri, W. S., Warditiani, N. K., \& Larasanty, L. P. F. 20I3. Skrining fitokimia ekstrak etil asetat kulit buah manggis (Garcinia mangostana L.). Jurnal Farmasi Udayana.

17. Hanani E. 20/4. Analisis Fitokimia. Penerbit Buku Kedokteran. ECG ., editor. Jakarta

18. Banu, R., \& Nagarajan, N. 2014. TLC and HPTLC fingerprinting of leaf extracts of Wedelia chinensis (Osbeck) Merrill. lournal of Pharmacognosy and Phytochemistry, 2(6).

19. Kristanti, A.N., Aminah, N. S., Tanjung, M.B. 2008. Buku Ajar Fitokimia : Airlangga. Surabaya

20. Yulianty, R., Rante, H., Alam, G., \& Tahir, A. 20II. Skrining dan Analisis KLT-Bioautografi Senyawa Antimikroba Beberapa Ekstrak Spons Asal Perairan Laut Pulau Barrang Lompo, Sulawesi Selatan. Majalah Obat Tradisional, I6(02), 88-94. 
21. Azis, A., Prayitno, T. A., Lukmandaru, G., \& Listyanto, T. 2015. Aktivitas Antirayap Ekstrak Daun Orthosiphon sp., Morinda sp., dan Carica sp. Jurnal Ilmu dan Teknologi Kayu Tropis, 13(2), I6I-I74.

22. Salamah, E., Ayuningrat, E., \& Purwaningsih, S. 2008. Penapisan awal komponen bioaktif dari kijing taiwan (Anadonta woodiana Lea.) sebagai senyawa antioksidan. Buletin Teknologi Hasil Perikanan, I I (2), II9-I32

23. Voight, R. 1995, Buku Pelajaran Teknologi Farmasi Edisi 5, diterjemahkan dari Bahasa Inggris oleh Soendadi Noerono Soewandhi, Gadjah Mada University Press, Yogyakarta.

24. Harbone, J. B. 1987. Metode Fitokimia : Penuntun Cara Modern Menganalisis Tumbuhan. Bandung: Institusi Teknologi Bandung.

25. Departemen Kesehatan Republik Indonesia, 1995, Farmakope Indonesia, Edisi IV, 606, Departemen Kesehatan Republik Indonesia, Jakarta.

26. Rejeki, D., Pratiwi, A., Ardita, D., Kusumawati, H. N., Wulandari, D., \& Maulida, A. 20I2. Penentuan kualitas pangan dan uji organoleptik. Makalah, Universitas Diponegoro, Fakultas Kedokteran, Semarang.

27. Ajeng, R. G., \& Asngad, A. 2016. Uji Organoleptik dan antioksidan teh daun kelor dan kulit jeruk purut dengan variasi suhu pengeringan (Doctoral dissertation, Universitas Muhammadiyah Surakarta).

28. Yustinah, Y. 2016. Ekstraksi Minyak Atsiri Dari Kulit Jeruk Sebagai Bahan Tambahan Pada Pembuatan Sabun. JURNAL KONVERSI, 5(I), 25-30.

29. Robinson, T. 1983. The Organic Constituents of Higher Plants Their Chemistry and Interrelationships,. 5th Ed., 2. Cordus Press., North Amherst.;

30. Prashant.20II. Pytochemical Screening and Extrac t. Internationale Pharmaceutica Science, I (I) : I9.

31. Svehla, G. (1985). Analisis anorganik kualitatif makro dan semimikro. Edisi kelima, bagian $I$. Jakarta: Kalman Media Pustaka.

32. Malangngi, L., Sangi, M., \& Paendong, I. (20/2). Penentuan kandungan tanin dan uji aktivitas antioksidan ekstrak biji buah alpukat (Persea americana Mill.). Jurnal Mipa, I(I), 5-I0.
33. Sangi, M., Runtuwene, M. R., Simbala, H. E., \& Makang, V. M. 2019. Analisis fitokimia tumbuhan obat di Kabupaten Minahasa Utara. Chemistry Progress, I(I), 47-53.

34. Gandjar, I. G. dan Rohman, A. 2007. Kimia Farmasi Analisis. Yogyakarta: Pustaka Pelajar

35. Hakim, A., Liliasari, L., Kadarohman, A., Syah, Y. M., \& Musthapa, I. 2017. Pembelajaran Kimia Bahan Alam Inovatif Melalui Praktikum. Procedia Kimia, I(I).

36. Wagner, H., \& Bladt, S. 1996. Plant drug analysis: $a$ thin layer chromatography atlas. Springer Science \& Business Media.

37. Molyneux, P. 2004. The use of the stable free radical diphenylpicrylhydrazyl (DPPH) for estimating antioxidant activity. Songklanakarin J. sci. technol, 26(2), 2II-2I9.

38. Regina, A., Maimunah, M., \& Yovita, L. 2008. Penentuan Aktivitas Antioksidan, Kadar Fenolat Total dan Likopen pada Buah Tomat (Solanum lycopersicum L). J. Sains dan Teknol. Farm.

39. Blois, M. S. 1958. Antioxidant determinations by the use of a stable free radical. Nature, I8I(46I7), II99-1200.

40. Middleton, E., Kandaswami, C., \& Theoharides, T. C. 2000. The effects of plant flavonoids on mammalian cells: implications for inflammation, heart disease, and cancer. Pharmacological reviews, 52(4), 673-75I.

4I. Fukumoto, L. R., \& Mazza, G. 2000. Assessing antioxidant and prooxidant activities of phenolic compounds. lournal of agricultural and food chemistry, 48(8), 3597-3604.

42. Burda, S., \& Oleszek, W. 200I. Antioxidant and antiradical activities of flavonoids. lournal of agricultural and food chemistry, 49(6), 2774-2779. 